\title{
Knowledge of HIV/AIDS, its Sources and Behaviour Change of Undergraduate Students of Ekiti State University South West Nigeria: Implications for Counselling
}

\author{
Assoc. Prof (MRS) Anna Onoyase ${ }^{1}$ \\ ${ }^{1}$ Department of Guidance and Counselling, Delta State University, P.M.B. 1 Abraka, Delta Stage, Nigeria \\ Correspondence: Assoc. Prof (MRS) Anna Onoyase ${ }^{1}$, Department of Guidance and Counselling, Delta State \\ University, A,braka, Nigeria. E-mail: tinaonoyase@gmail.com
}

Received: October 5, 2019

doi:10.5430/ijhe.v9n1p81

Accepted: November 14, $2019 \quad$ Online Published: November 15, 2019

URL: https://doi.org/10.5430/ijhe.v9n1p81

\begin{abstract}
This research was embarked upon to find out about knowledge of HIV/AIDS, its sources and behaviour change of undergraduate university students of Ekiti State University, South west Nigeria: Implications for counselling. In order to carry out the investigation, the researcher formulated three research questions and one hypothesis to guide the investigation. The instrument used in the collection of data is "Knowledge of HIV/AIDS, its Sources and Behaviour Change Questionnaire" (KHASBCQ). The instrument that was made up of 26 items was subjected to a reliability test. The instrument was administered on 30 respondents who were not part of the main investigation. The test- retest was used to analyse the data collected from the 30 respondents. The reliability coefficient obtained was 0.87 . The instrument, have language appropriateness and content validity. The investigator used 2 research assistants to administer 251 copies of the questionnaire on the respondents in the university. The research assistants retrieved 210 copies of the questionnaire from the respondents. The mean and standard deviation were used to answer the research questions and the $t$ - test was used to test the hypothesis at 0.05 level of significance. The findings showed that the undergraduate university students have knowledge of HIV/AIDs. The sources of knowledge of HIV/AIDS by the students include: television, newspaper, friends and internet. The knowledge of HIV/AIDs by the students have led to behaviour change in them. There is behaviour change in the students because they no longer indulge in anal sex, they now have sex with only one partner, they make use of condom when having sexual intercourse. One of the recommendations is that both government and private radio networks are advised to educate the students and entire members of the society about the existence of HIV/AIDS so that they can have behaviour change such as having only one sexual partner.
\end{abstract}

Keywords: Knowledge, HIV/AIDs, sources, behaviour change

\section{Introduction}

It is no longer news that Human Immune Deficiency Virus (HIV), including the Acquired Immune Deficiency Syndrome (AIDS) has become a serious health challenge that is ravaging the entire world. Osagbemi, Joseph, Adepetu, Nyong and Jegede (2007), reported that the epidemic is considered a threat to the economic well - being, social and political stability of many nations. It is one of the greatest humanitarian and development challenges facing the global community including Nigeria. UNAIDS (2007) stated that human immune deficiency virus (HIV) and acquired immune deficiency syndrome (AIDS), continue to spread around the world and it is the leading course of death in some people. From observation, a good number of students are aware of the prevalence of HIV/AIDs, yet such knowledge appear not have brought changes in their HIV/AIDs prone behaviour.

\section{Review of Related Literature}

Omoteso, Adeniyi and Bada (2010), maintained that the fight against HIV/AIDS has gradually geared up governments, international agencies and non- governmental organizations to take action on how to reduce the scourge of the disease. Omoteso, Adeniyi and Bada (2010), stressed that the main sources of transmission of HIV/AIDS is through:

- Using unsterilized hypodemic needles and syringes,

- Blood from an infected person entering a cut or an open wound, 
- Mother to baby either before, during or after birth.

- Unprotected penetrative sexual contact and other risky behaviour and this account for $80 \%$ of cases of HIV protection, and

- Blood transfusion with contaminated blood of donor.

Ada, Chinyelu, Ebele and Ifeoma (2011: 156), opined that HIV/AIDs infection has grave social, economic and psychological implications for the individual, the family and the society at large. They went further to say that despite the devastating effects on the society, no cure has yet been found to the treatment of the disease and human existence is being threatened.

Avent (2007), opined that the prevalence rates of HIV/AIDs among the young people between the ages of 20 and 24 were 5.6\%. Continuing Avent (2007), reported that in 2005, there were about 220,000 deaths from AIDS and 130,000 orphans are presently living in Nigeria. Omoteso, Adeniyi and Bada (2010), pointed out that due to non availability of credible curative drugs and vaccines, probably the only available way for dealing with HIV/AIDs on a large scale is through developing appropriate standards of behaviour.

Adekeye (2009), investigated "HIV voluntary counselling and testing for young people: the antidote for a healthy and positive living in Nigeria". The target population for the study was all young persons between 15 and 24 years in Nigeria. The category of young people that were used in the study were, students 303, traders 180, and artisans 122. A self - made instrument titled, questionnaire on HIV VCT (QHIVCT) was used to collect information for the investigation. It had 59 items. The data collected were analysed with descriptive and inferential methods, that is, percentages, t- test and regression analysis. Some findings of the research showed that most young people know that HIV/AIDs is presently incurable, 98 percent identified sexual intercourse without condoms as one of the sources of transmitting HIV/AIDs, 99 percent identified using condom during sex to prevent HIV/AIDs, 97 percent and 76 percent identified faithfulness to one's partner and abstaining from sex as means of preventing HIV/AIDs respectively. The investigation found out the followings as sources of information about HIV/AIDs, radio 92 percent, television 87 percent, family members 77 percent, posters/ bill boards 65 percent, nurses 43 percent and doctors 21 percent. Others are magazines 28 percent, church/ mosque 19 percent, newspaper 21 percent, friends 33 percent, teachers 45 percent and parents 56 percent.

The finding equally showed that there is a significant difference in the disposition to HIV VCT between respondents who have experienced sexual intercourse and those who have not. The hypothesis which says, there will be no significant difference in the disposition to HIV VCT between respondents who have engaged in sex in the last six months and those who have not, was accepted. The finding equally revealed that sex and age would significantly predict attitude of young people towards HIV VCT when combined, both sex and age predicted about 41 percent of the variation in attitude towards HIV VCT.

Ada, Chinyelu, Ebele and Ifeoma (2011: 154), investigated influence of knowledge of HIV/AIDs behaviour change among adolescents in Anambra State, Nigeria. One of the objectives of the study was to determine the knowledge of the adolescents about HIV/AIDs. The population of the study consisted of 9,000 adolescents in 264 secondary schools in Anambra State. A sample of 960 adolescents were used for the investigation. An instrument referred to as "Questionnaire on Knowledge of HIV/AIDs and Behavioural Changes" (QKBC) was used to obtain information for the research. The data collected were analysed with percentages, $t$ - test and chi-square. Some of the findings indicated that adolescents' knowledge about HIV/AIDs was high, about 81 percent of the adolescents had stopped having deep kissing while 19 percent had not done so, about 55 percent have stopped having sexual intercourse, while 45 percent would like to continue, 63 percent of the adolescents started using condoms when having sexual intercourse and 27 percent continued to sex without condoms, 35 percent of the adolescents took their clippers to their barbers and 65 percent did not involve themselves in anal sex while 7 percent were involved in it. The adolescents that had sex with one partners were 55 percent and 45 percent had multitude partners. The findings also revealed that the factors influencing behaviour changes among adolescents in relation to HIV/AIDs were: fear of dying 96 percent, stigmatization 63 percent, peer group pressure influence 88 percent, seeing HIV/AIDs infected person 89 percent, HIV/AIDs awareness programme influence, 55 percent, 20 percent were influenced by parental communication on HIV/AIDs, 33 percent were influenced by health impact of the disease, 27 percent were influenced by social impact of the disease and 32 percent were influenced by sensitization from school counsellor. The investigation revealed that there is no significant difference in the knowledge of urban and rural adolescents about HIV/AIDs. 
Omoteso, Adeniyi and Bada (2010: 7), investigated the influence of the knowledge of HIV/AIDs on behaviour change among undergraduate students of the Faculty of Education, Obafemi Awolowo University, Ile - Ife, Osun State, South West, Nigeria. Some of the objectives were:

- to find out the knowledge of the students about HIV/AIDs,

- to examine the patterns of behaviour changes in relation to HIV/AIDs among students, and

- to establish the factors influencing the behaviour changes of the students.

A sample of 200 students, made up of 87 males and 113 females were used in the investigation from the Faculty of Education. The instrument for data collection is tagged, Questionnaire on Knowledge of HIV/AIDs and Behaviour Changes" (QKBC), section A of the instrument consisted of demographic variables such as age, sex and level of the student. Section B comprised items on knowledge of HIV/AIDs among the students. Section C was made up of items on behavioural changes that have taken place in the students. Section D consisted of items on the factors influencing students' behavioural changes such as peer group pressure, stigmatization and fear of being infected. Some of the findings of the investigation were; that 194 (92\%) of the students know that one can be infected with HIV/AIDs, but $16(8 \%)$ of the students weren't aware of this. The students who knew that HIV/AIDs could be contacted through blood transfusion and sharing of syringes and needles were 179 (89.5\%), while 21 (10.5\%) did not know this. Also, 177 (88.5\%), of the students knew that HIV/AIDs could be contacted through the use of unsterilized equipment like clippers while $23(11.5 \%)$ did not have this knowledge. Students who indicated that one can be infected with HIV/AIDs were $91 \%$, through circumcision, $70.5 \%$, open cut or wound $56.6 \%$ and through anal sex $57 \%$. The results indicated that 97(48.5\%) had stopped having sexual intercourse while $103(51.5 \%)$ had not done so. The students that were having sexual intercourse with just one partner were $127(63.5 \%)$ and $73(36.5 \%)$ respectively. About $72 \%$ of the students were using condoms while having sexual intercourse. About $48(24 \%)$ of the students indicated to continue to abstain from sex and $179(89.5 \%)$ were avoiding the use of unsterilized injection needles, surgical and skin piercing instruments. A total of $112(56 \%)$ of the students were taking clippers, manicure and pedicure kits to their barbers and hair- dressers, while $82(44 \%)$ were not doing so. The students who no longer engaged in kissing were $76 \%$ and $24 \%$ were found to be doing so.

The investigation revealed that the factors influencing behaviour changes among the students with regard to HIV/AIDs were: knowledge was mentioned by $121(61 \%)$ ranks $1^{\text {st }}$, peer group pressure $119(60 \%)$ ranks $2^{\text {nd }}$ stigmatization $88(44 \%)$ ranks $3^{\text {rd }}$, seeing an HIV/AIDs infected person $85(45 \%)$ ranks $4^{\text {th }}$ and fear of being infected $38(75 \%)$ ranks 5th, others are HIV/AIDs awareness programmes $75(37 \%)$ ranks $6^{\text {th }}$ parental communication on HIV/AIDs 31(62\%) ranks 7th, health impact of the disease 59(30\%) ranks $8^{\text {th }}$, economic impact of the disease $49(24.5 \%)$ ranks $9^{\text {th }}$ and social impact of the disease $48(24 \%)$ ranks $10^{\text {th }}$.

Ewhrudjakpo (2009), conducted a research on the knowledge and attitude to HIV voluntary counselling and testing among students of tertiary institutions in Delta State, Nigeria. The researcher sampled 2,815 respondents from 14 tertiary institutions using simple random sampling technique. The results revealed that, tertiary institution students have a negative attitude towards HIV voluntary counselling and testing VGT. Students' good knowledge of HIV does not relate negatively to their attitude towards HIV VCT.

Akanbi (2010), carried out a research on socio-demographic factor influencing HIV/AIDs stigmatization and discrimination among women in Lagos State, Nigeria. The researcher randomly selected 230 women who are HIV/AIDs positive from 3 public hospitals in Lagos State. The main instrument used was the questionnaire and personal interviews. Frequency table and regression model were employed in the analysis of data collected from the field. The findings showed that women who discovered their HIV/AIDs status were gossiped about, verbally harassed and neglected by the society, stigmatized and discriminated against.

Ofuoku (2017), carried out an investigation of HIV/AIDs awareness and communication methods in disseminating messages among students in Delta Central Senatorial district, Delta State, Nigeria. The population consisted of junior secondary school 2 students and senior secondary school 2 students in public and private secondary schools in Delta Central Senatorial District. The random sampling technique was utilized in selecting 360 respondents from the public secondary schools and 640 respondents from the private secondary school. The instrument used for data collection was HIV/AIDs awareness questionnaire. The mean, standard deviation and t-test statistics were used to analyse the data collected from the field. Findings showed that there was significant difference in the awareness level of male and female students about causes and model means of transmission of HIV/AIDs infection, there was no significant difference in the awareness level of prevention measure of HIV/AIDs, there was no significant location difference 
about the awareness level of causes and prevention measure of HIV/AIDs and there was no significant difference between urban and rural students awareness level about the model means of transmission of HIV/AIDs infection.

\section{Operational Definition of Terms}

Behaviour Change: This refers to steps taken by the undergraduate university students to avoid contacting HIV/ AID e.g. using condom when having sexual intercourse.

\section{Statement of the Problem}

It is no longer news that HIV/AIDs is ravaging many countries of the world and therefore has become a global problem. Today, many people may be living with HIV/AIDs and yet no definite drug has been found for its cure. The literature reviewed has revealed to the researcher that some sources of transmission of HIV/AIDs include, using unsterilized hypodemic needles and syringes, mother to baby either before, during and after birth and unprotected penetration contact and other risky sexual behaviour.

The problem of this research put in a question form is whether students have knowledge of HIV/AIDS, its sources and if the knowledge of HIV/AIDs by students is in their behaviour change? Specifically, the research will provide answers to the following questions:

1. What is the knowledge of undergraduate university students about HIV/AIDs?

2. What are the sources of knowledge of undergraduate university students about HIV/AIDs?

3. What is the behaviour change of undergraduate university students as a result of their knowledge about HIV/AIDs?

\section{Hypothesis}

There is no significant difference between male and female undergraduate university students in their behaviour change as a result of their knowledge about HIV/AIDS

\section{Research Method and Procedure}

The research design adopted for this investigation is Ex-post facto using survey technique. Survey technique involves the sampling of opinion of a large number of respondents from the population. Egbule and Okobia (2012: 28), stated that survey studies are very valuable and advantageous because they have wide range of scope, a great deal of information as well as representative samples and generalization to the entire population. This makes survey studies very economical for independent researchers. The population of the investigation is made up of students of Ekiti State University South West Nigeria. The investigator made use of an instrument tagged, knowledge of HIV/AIDs, Its sources and behaviour change questionnaire (KHASBCQ) to elicit information for the research. The instrument consists of 26 items, 5 items on knowledge of HIV/AIDs, 11 on sources of knowledge of HIV/AIDs and 10 on behaviour change of the students as a result of their knowledge about HIV/AIDs. All the 26 items of the instrument have the rating scale of 4 points: Strongly Agreed (SA) $=4$ points, Agreed (A) 3 points; Disagreed (SD), 2 points and Strongly Disagreed (SD) 1 point. The instrument has a reliability coefficient of 0.91 and has facial, and content validity. It equally has language appropriateness. Some of the 26 items in the instrument were adopted from Adekeye (2009: 18), Omoteso, et al., (2010: 11).

The researcher used purposive sampling technique to select 251 students that participated in the study. The investigator used 2 research assistants to administer 251 copies of the instrument on the respondents in the university. The research assistants retrieved 210 copies of the questionnaire from the students showing about 83.6 percent return rate. The investigator collated the information gathered from the field and used mean and standard deviation to answer the research questions while the $t$ - test was used to test the hypothesis. The benchmark of 2.50 was chosen to determine whether respondents agreed or disagreed with each of the 26 items. The t- test was used to test the hypothesis at 0.05 level of significance.

\section{Findings}

\section{Research Question 1}

What is the knowledge of undergraduate university students about HIV/AIDs? 
Table 1. Mean and standard deviation analysis of knowledge of HIV/AIDs of undergraduate university students. $\mathrm{N}=$ 210 .

\begin{tabular}{|c|c|c|c|c|}
\hline $\mathrm{S} / \mathrm{N}$ & Items & Mean & $\begin{array}{l}\text { Standard } \\
\text { deviation }\end{array}$ & Decision \\
\hline 1 & I have heard about HIV/AIDs. & 3.12 & 0.93 & Agreed \\
\hline 2 & I have heard that HIV/AIDs is prevalent in Nigeria. & 2.80 & 1.03 & Agreed \\
\hline 3 & I have heard that HIV/AIDs has no cure. & 2.96 & 1.01 & Agreed \\
\hline 4 & $\begin{array}{l}\text { I have heard that HIV/AIDs can be managed throughout } \\
\text { life. }\end{array}$ & 3.07 & 1.04 & Agreed \\
\hline \multirow[t]{2}{*}{5} & $\begin{array}{l}\text { I have heard that HIV/AIDs has killed some people in } \\
\text { Nigeria. }\end{array}$ & 3.07 & 1.04 & Agreed \\
\hline & Mean & 2.99 & 1.01 & Agreed \\
\hline
\end{tabular}

The research has found out that the undergraduate university students have knowledge about HIV/AIDs. This is because all the five items on table one have mean above the benchmark of 2.50 .

\section{Research Question 2:}

Table 2. Mean and standard deviation analysis of the sources of knowledge of undergraduate university students about HIV/AIDs

\begin{tabular}{|c|c|c|c|c|}
\hline $\mathrm{S} / \mathrm{N}$ & Items & Mean & $\begin{array}{l}\text { Standard } \\
\text { deviation }\end{array}$ & Decision \\
\hline 1 & My knowledge about HIV/AIDs is obtained from the radio. & 2.38 & 1.11 & Disagreed \\
\hline 2 & $\begin{array}{l}\text { I became aware of HIV/AIDs through programmes on the } \\
\text { television. }\end{array}$ & 2.54 & 1.08 & Agreed \\
\hline 3 & $\begin{array}{l}\text { My knowledge about HIV/AIDs was gotten from my } \\
\text { friends. }\end{array}$ & 2.53 & 1.11 & Agreed \\
\hline 4 & $\begin{array}{l}\text { Members of my family created awareness in me about } \\
\text { HIV/AIDs. }\end{array}$ & 2.79 & 0.96 & Agreed \\
\hline 5 & $\begin{array}{l}\text { I obtained information about HIV/AIDS from posters/ bill } \\
\text { boards in the university health centre. }\end{array}$ & 2.52 & 1.16 & Agreed \\
\hline 6 & $\begin{array}{l}\text { I got to know about HIV/AIDS from programmes } \\
\text { organized in the university counselling centre. }\end{array}$ & 2.50 & 1.14 & Agreed \\
\hline 7 & $\begin{array}{l}\text { I obtained information about HIV/AIDS through fellowship } \\
\text { in my church. }\end{array}$ & 2.29 & 1.05 & Disagreed \\
\hline 8 & It was in the mosque that I got to know about HIV/AIDs. & 2.26 & 1.02 & Disagreed \\
\hline 9 & My knowledge about HIV/AIDS was from the internet. & 2.85 & 0.98 & Agreed \\
\hline 10 & I read about HIV/AIDS in the newspaper. & 2.65 & 1.05 & Agreed \\
\hline 11 & $\begin{array}{l}\text { The source of my knowledge about HIV/AIDS was from } \\
\text { my lecturers. }\end{array}$ & 2.68 & 1.06 & Agreed \\
\hline
\end{tabular}

The investigation has revealed in table two that some of the sources of knowledge of HIV/AIDs by the undergraduate university students include; television with mean score of 2.54, from friends with mean score of 2.53 , members of family with mean score of 2.79 , posters/ bill boards of the university health centre with mean score of 2.52 , and programmes organized in the university counselling centre with mean score of 2.50. Others include internet with mean score of 2.65 and lecturers with mean score of 2.68. The total grand mean score is 2.54. All the mean scores including the total grand mean were above the benchmark of 2.50 . This is why all of them are sources of knowledge of HIV/AIDs to the undergraduate university students. The research found out in table two that the undergraduate university students did not get their knowledge of HIV/AIDs from the radio with mean score of 2.38 , from fellowship in the church with mean score of 2.29 and from the mosque with mean score of 2.26. This is because the mean scores from radio, church and mosque are below the benchmark of 2.50 . 


\section{Research Question 3}

What is the behaviour change of undergraduate university students as a result of their knowledge about HIV/AIDS.

Table 3. Mean and standard deviation analysis of the behaviour change of undergraduate university students as a result of their knowledge about HIV/AIDs $\mathrm{N}=210$.

\begin{tabular}{|c|c|c|c|c|}
\hline $\mathbf{S} / \mathbf{N}$ & Items & Mean & $\begin{array}{l}\text { Standard } \\
\text { deviation }\end{array}$ & Decision \\
\hline 1 & I no longer indulge in commercial sex. & 2.67 & 1.01 & Agreed \\
\hline 2 & I now use condom when having sexual intercourse. & 3.01 & 0.85 & Agreed \\
\hline 3 & I now have sex with only one partner. & 3.03 & 0.90 & Agreed \\
\hline 4 & $\begin{array}{l}\text { I have stopped attending night parties in order to avoid } \\
\text { indiscriminate sex. }\end{array}$ & 2.72 & 1.07 & Agreed \\
\hline 5 & I no longer indulge in anal sex. & 2.70 & 1.06 & Agreed \\
\hline 6 & I no longer accept transfusion of unscreened blood. & 2.76 & 1.05 & Agreed \\
\hline 7 & I have stopped using unsterilized needles and syringes. & 2.73 & 1.06 & Agreed \\
\hline 8 & I no longer share shaving sticks with my friends. & 2.95 & 0.84 & Agreed \\
\hline 9 & I now use my own clipper and combs in the barbing saloon. & 2.71 & 1.02 & Agreed \\
\hline \multirow[t]{2}{*}{10} & I have stopped having deep kissing. & 2.71 & 1.01 & Agreed \\
\hline & Grand mean & 2.80 & 0.99 & Agreed \\
\hline
\end{tabular}

The research has found out in table 3, that the undergraduate university students agreed to all the ten items that their behaviours have changed as a result of their knowledge about HIV/AIDs. The students no longer indulge in commercial sex, with mean score of 2.67, the students now use condom when having sexual intercourse, with mean score of 3.01, the students now have sex with one partner, with a mean score of 3.03. The students have stopped attending night parties in order to avoid indiscriminate sex, with mean score of 2.72 . The investigation on table 3 revealed that the students no longer indulge in anal sex with mean score of 2.70 . The students no longer accept transfusion of unscreened blood, with mean score of 2.76. The undergraduate university students have stopped using unsterilized needles and syringes, with mean score of 2.73. The students no longer share shaving sticks with their friends, with mean score of 2.95. The students now use their own clippers and combs in the barbing saloon with mean score of 2.71. The students have stopped having deep kissing, with mean score of 2.71 . The grand mean score is 2.80 . The ten mean scores and grand mean score were above the benchmark of 2.50 .

\section{Hypothesis}

There is no significant difference between male and female undergraduate university students in their behaviour change as a result of their knowledge about HIV/AIDs.

Table 4. $\mathrm{t}$ - test on the difference between male and female undergraduate university students in their behaviour change as a result of their knowledge about HIV/AIDs.

\begin{tabular}{ccccccccc}
\hline Variables & $\mathrm{N}$ & $\mathrm{X}$ & $\mathrm{SD}$ & $\mathrm{Df}$ & $\begin{array}{c}\text { Level of } \\
\text { sign. }\end{array}$ & t. cal & t. crit. & Decision \\
\hline Male students & 101 & 40.39 & 4.88 & 208 & 0.05 & -8.26 & .025 & Significant \\
Female students & 109 & 45.40 & 3.90 & & & &
\end{tabular}

The data in table 4 showed a t- test summary on the difference between male and female undergraduate students in their behaviour change as a result of their knowledge about HIV/AIDs. The result of the investigation indicated that t- calculated value of -8.26 was higher than t- critical value of .025 with 208 degree of freedom at 0.05 level of significance. This implies that there is a significant difference between male and female undergraduate university students in their behaviour change as a result of their knowledge about HIV/AIDs.

\section{Discussion}

The research has revealed that television, family members and posters/ bill boards in the university health centre were some of the sources of knowledge of the undergraduate university students about HIV/AIDs. This finding lends credence to that of Adekeye (2009). Adekeye investigated "HIV voluntary counselling and testing for young people: 
the antidote for a healthy and positive living in Nigeria" and found out that television, family members and posters/ bill boards were sources of knowledge of HIV to the subjects of the research.

The investigation equally revealed, that as a result of the knowledge of HIV/AIDs to the undergraduate university students, they now have behaviour change. The students now use condom when having sexual intercourse, the students have stopped using unsterilized needles and syringes, they now use their clippers and combs in the barbing saloon and the students have stopped deep kissing. These findings agreed with those of Omoteso et al., (2010). Omoteso et al., (2010) investigated the influence of the "knowledge of HIV/AIDs on behaviour change among undergraduate students of the Faculty of Education Obafemi Awolowo University, Ile - Ife, Osun State, South West Nigeria" and found out that about $72 \%$ of the students were now using condom when having sexual intercourse, $89.5 \%$ of the students avoided the use of unsterilized infection needles, $56 \%$ of the students were found to be taking clippers, manicure and pedicure kit to their barbers and $76 \%$ of the students no longer engaged in kissing.

The present research equally supports Ada et al., (2011). Ada et al (2011) investigated "influence of knowledge of HIV/AIDs on behaviour change among adolescents in Anambra State Nigeria" and their research found out that about $81 \%$ of the adolescents used for the investigation had stopped having deep kissing, $63 \%$ of them have started using condoms when having sexual intercourse, $93 \%$ of the adolescents no longer involve themselves in anal sex and $55 \%$ of them were found to have sex with only one partner.

The research revealed that there is a significant difference between male and female undergraduate university students in their behaviour change as a result of their knowledge about HIV/AIDs. This finding contradicts that of Ada et al. (2011) who found out that there is no significant difference between the urban and rural adolescents in their behaviour change as a result of their knowledge about HIV/AIDs.

\section{Conclusion}

The conclusion that can be drawn as a result of the findings is that the undergraduate university students have knowledge about HIV/AIDs. The sources of their knowledge include, television, family members, through posters/ bill boards in the university health centre and from their lecturers. The knowledge about HIV/AIDs possessed by the students have led to behaviour change in them because they no longer indulge in commercial sex, and don't accept transmission of unscreened blood.

\section{Recommendations}

As a result of the findings and conclusion reached, the following recommendations have been proposed by the researcher:

1.Both government and private radio net works are advised to educate the students and the entire members of the society about the existence of HIV/AIDs.

2.The church and the mosque should be used as a source of providing information to the students about the presence of HIV/AIDs in our society. The church and mosque can do it through health talk.

\section{Implications for Counselling}

The followings are the implications of the research.

1.There is need for the government (state and federal), to establish counselling centres in all universities in Nigeria and employ adequate number of counsellors to man such centres.

2.University counsellors are to liaise with radio stations on the need to slot in some programmes on HIV/AIDs to create awareness.

3.Counsellors in universities should collaborate with the Department of Mass Communication and work out modalities on how information on HIV/AIDs will be disseminated regularly to students through university radio stations.

4.University counsellors in various churches and mosques are to work hand in hand with their Pastors and Imams in order to incorporate HIV/AIDs information in daily/ weekly programmes so as to sensitize more students on the dangers of HIV/AIDs.

\section{References}

Ada, A., Chinyelu, N., Ebele, A. \& Ifeoma, O. O. (2017). Influence of the knowledge of HIV/AIDs on behaviour change among adolescents in Anambra State, Nigeria, International Journal of Psychology and Counselling, $3(8), 154-158$. 
Adekeye, O. A. (2009). HIV voluntary counselling and testing for young people: The Antidote for a healthy and positive living in Nigeria, The Counsellor, 26(2).

Akanbi, M. A. (2010). Socio- demographic factors influencing HIV/AIDs stigmatization and discrimination among women in Lagos State. Academic Journal Article and Gender Behaviour, 8(2), 3209-3225. https://doi.org/10.4314/gab.v8i2.61942

Avent (2007). The impact of HIV/AIDs on Africa. Retrieved on June $1^{\text {st }} 2007$. http://www.theimpacto,fhiv/aidsonafrica,htm/ files: ilc.

Egbule, J. F. \& Okobia, D. O. (2012). Research methods in Education for Colleges and Universities, Agbor, Kmensuo Educational Publishers.

Ewhrudjako, C. (2009). Knowledge and attitude to HIV voluntary counselling and testing among students in tertiary institutions in Delta State, Nigeria, Journal of Research in National Development, 7(2). www.transcompus.org jorin.dv 7 dec. 2009. https://doi.org/10.4314/jorind.v7i2.50954

Ofuoku, F. E. (2017). Survey of HIV/AIDs awareness and communication methods in disseminating message among students in Delta Central Senatorial district, Delta State, Nigeria, Unpublished M.Ed dissertation in guidance and counselling, Delta State University, Abraka, Nigeria.

Omotoso, B. A., Adeniyi, O. \& Bada, T. (2010). The influence of the knowledge of HIV/AIDS on behaviour change among undergraduate students of faculty of education, Obafemi Awolowo University, CASSON, 27, 7-20.

Osagbemi, M. O., Joseph, B., Adepetu, A. A., Nyong, A. O. \& Jegede, A. S. (2007). Culture and HIV/AIDs in Africa promoting reproductive health in light of spouse - sharing practice among the Okun, people, Nigeria, World Health and Population. Toronto Longwoods publishing. https://doi.org/10.12927/whp.2007.18970

UNAIDS, (2007). 2007 AIDS Epidemic update. Retrieved on 21 January 2008 from http://data.unaids.org/pub/ Epislides/ 2007/ 2007- ep. Update en.pdf. 